PERM JOURNAL OF PETROLEUM AND MINING ENGINEERING

ВЕСТНИК ПНИПУ. ГЕОЛОГИЯ. НЕФТЕГАЗОВОЕ И ГОРНОЕ ДЕЛО

ISSN 2224-9923

Volume/Tom 16 №4 2017

http://vestnik.pstu.ru/geo/

УДК 622.245.14+622.257.12

Article / Статья

(c) PNRPU / ПНИПУ, 2017

\title{
DEVELOPMENT OF SLURRIES AND STUDY OF PROPERTIES OF CEMENT MIXTURES TO INCREASE THE QUALITY OF WELL COMPLETION
}

\section{Nikolay I. Nikolaev, Ruslan A. Usmanov ${ }^{1}$, Seyyed Sh. Tabatabaee Moradi, Jennifer R. Hernandez Requena}

Saint-Petersburg Mining University (2 $21^{\text {st }}$ Line, Vasilyevskiy island, Saint Petersburg, 199106, Russian Federation)

${ }^{1}$ Almetyevsk State Oil Institute (2 Lenina st., Almetyevsk, 423450, Russian Federation)

\section{РАЗРАБОТКА СОСТАВОВ И ИССЛЕДОВАНИЕ СВОЙСТВ ТАМПОНАЖНЫХ СМЕСЕЙ ДЛЯ ПОВЫШЕНИЯ КАЧЕСТВА ВТОРИЧНОГО ВСКРЫТИЯ ПРОДУКТИВНЫХ ПЛАСТОВ}

\author{
Н.И. Николаев, Р.А. Усманов ${ }^{1}$, С.Ш. Табатабаи Моради, Дж.Р. Эрнандес Рекена \\ Санкт-Петербургский горный университет (199106, Россия, г. Санкт-Петербург, Васильевский остров, 21-я линия, 2) \\ ${ }^{1}$ Альметьевский государственный нефтяной университет (423450, Россия, г. Альметьевск, ул. Ленина, 2)
}

Received / Получена: 15.09.2017. Accepted / Принята: 01.10.2017. Published / Опубликована: 01.12.2017

\section{Key words:}

cementing, completion, cement slurry, cement stone, perforation, plastic strength, plasticizer compressive strength, bend strength, adhesion, surfactants, polymers, consistency, well casing, chemical agents.

\begin{abstract}
Physical and mechanical properties of polymer cement slurries and cement stone are studied. The goal of the work is to improve the quality of completion of productive formations by development of polymer cement mixtures with improved structural and mechanical characteristics of a cementing slurry and cement stone. During the completion a special attention is paid to the preservation of well cement stone quality. So, there is a brittle fracture of the cement stone occur because of the dynamic loads caused by cumulative and bullet perforation, as well as the torpedoing of casing strings. Using such methods of well completion a cement stone can be destroyed both in perforation intervals and in places of bridges that separate productive layers from aquifers. The consequence of that opening is the accelerated growgh of water cut of wells. Despite the high technical level of new types of perforators, they are not widely used in drilling of oil and gas wells because of the large time and metal consumption of the work performed and, consequently, high financial costs of their use. It is known that the integrity of the cement stone is ensured at perforation during the transition of the coagulation structure of a cement suspension to crystal one. For a normal cement slurry (water/cement $=0.5)$ that moment occurs relatively quickly $(7-15 \mathrm{~h})$, which is not enough for perforation operations. In order to modify the properties of a cement mixture the compositions of cation-active surfactant (catamine) and non-ionic polymer (polyvinylpyrrolidone) were chosen. Results of experimental studies show that the input of these agents into the composition of a cement mixture leads to an increase in spreadability of a cement slurry (more than $25 \mathrm{~cm}$ by the cone of Azerbaijan Scientific Research Institute), time of its bondability, strength of a cement stone for compression ( $200 \%$ after 28 days of hardening) and bending ( $250 \%$ ), adhesion of cement stone to metal (by $80 \%$ ) and time of coagulation structure setting. In addition, plastic properties of the developed cement slurry are retained for more than 19 hours. The influence of the agent (defoamer T-66) on the rate of cement stone strengthening is determined. It is shown that input of a nonionic high molecular polymer reduces the rate of the formation of crystal structure in a cementing mixture.
\end{abstract}

Исследуются физико-механические свойства полимерцементных тампонажных растворов и цементного камня. Цель работы - повышение качества вторичного вскрытия продуктивных пластов путем разработки полимерцементных смесей с улучшенными структурно-механическими характеристиками тампонажного раствора и цементного камня. При проведении вторичного вскрытия продуктивного пласта особое внимание уделяется сохранению качества крепи проведении вторичного вскрытия продуктивного пласта особое внимание уделяется сохранению качества крепи
скважины. Так, из-за динамических нагрузок, происходящих в результате проведения кумулятивной и пулевой скважины. Так, из-за динамических нагрузок, происходящих в результате проведения кумулятивной и пулевой способах вторичного вскрытия цементный камень может разрушаться не только в интервалах перфорации, но и в местах перемычек, отделяющих продуктивные пласты от водоносных. Следствием такого вскрытия является ускоренное обводнение скважин. Несмотря на высокий технический уровень новых видов перфораторов, они не находят широкого применения при бурении нефтяных и газовых скважин из-за больших затрат времени и металлоемкости проводимых применения при бурении нефтяных и газовых скважин из-за больших затрат времени и металлоемкости проводимых
работ, следовательно, больших финансовых затрат на их использование. Известно, что целостность цементного камня работ, следовательно, больших финансовых затрат на их использование. Известно, что целостность цементного камня в кристаллизационную. Для нормального тампонажного раствора (вода/цемент $=0,5)$ этот момент наступает относительно быстро (7-15 ч), и его не хватает для проведения перфорационных работ. С целью модификации свойств цементной смеси были выбраны композиции катионактивного поверхностно-активного вещества (катамина) и неионогенного полимера поли выбраны композиции катионактивного поверхностно-активного вещества (катамина) и неионогенного полимера поливинилпирролидона. Результаты экспериментальных исследований показывают, что ввод данных реагентов в состав
цементной смеси приводит к увеличению растекаемости тампонажного раствора (больше 25 см по конусу Азербайджанского научно-исследовательского института), сроков его схватывания, прочности цементного камня на сжатие (200\% после 28 суток твердения) и изгиб (250\%), сцепления цементного камня с металлом (на 80 \%) и времени набора коагуляционной структуры. Кроме этого, пластичные свойства разработанного тампонажного раствора сохраняются более 19 ч. Определено влияние реагента (пеногасителя Т-66) на интенсивность набора прочности цементного камня. Показано, что введение неионогенного высокомолекулярного полимера снижает интенсивность формирования кристаллической структуры в тампонажной смеси.

Nikolay I. Nikolaev (Author ID in Scopus: 56308406100) - Doctor of Engineering, Professor at the Department of Well Drilling (tel.: +007 812328 84 78, e-mail: nikinik@mail.ru). Ruslan A. Usmanov - PhD in Engineering, Associate Professor at the Department of Oil and Gas Well Drilling (tel.: +007 85533100 04, e-mail: bngs_agni@mail.ru). Seyyed Sh. Tabatabaee Moradi - PhD student at the Department of Well Drilling (tel.: +007 81232884 78, e-mail: s.sh.tabatabaee@gmail.com). The contact person for correspondence. Jennifer R. Hernandez Requena - PhD student at the Department of Well Drilling (tel.: +007 812328 84 78, e-mail: j.r.h.r@outlook.com).

Николаев Николай Иванович - доктор технических наук, профессор кафедры бурения скважин (тел.: +007 81232884 78, e-mail: nikinik@mail.ru). Усманов Руслан Айратович - кандидат технических наук, доцент кафедры бурения нефтяных и газовых скважин (тел.: +007 8553310004 , e-mail: bngs_agni@mail.ru). Табатабаи Моради Сейед Шахаб - аспирант кафедры бурения скважин (тел.: +007812328 84 78, e-mail: s.sh.tabatabaee@gmail.com). Контактное лицо для переписки. Джениффер Регина Эрнандес Рекена - аспирант кафедры бурения скважин (тел.: +007 812328 84 78, e-mail: j.r.h.r@outlook.com). 


\section{Introduction}

Today a special attention is paid to maintaining the quality of well casing during the well completion $[1,2]$. Due to dynamic loads that occur as a result of cumulative and bullet perforation, as well as torpedoing of casing columns, brittle fracture of a cement stone appeare [3, 4]. Such methods of well completion can cause destruction of a cement stone both at intervals of perforation and in places where bridges separate productive strata from aquifers. Accelerated increase of well water cut is the consequence of that.

In order to prevent cement stone from appearance of cracks during the well completion new types of perforation (drilling, hydraulic sandblasting, hydromechanical etc.) are used. Such methods affect the state of casing least $[5,6]$. Despite the high technical level of the new types of perforators, they are not widely used in oil and gas wells due to the large time, metal consumption (a large number of supplementary units, connection points etc.) and, therefore, large financial costs on their use.

One of the most promising ways to preserve the integrity of cement stone during the perforation is to control the physical and mechanical properties of cement stone by input of various chemical reagents including polymers into cement compositions [7]. High efficiency of such systems is determined by the ability to form a strong, high adhesion stone during the hardening, thereby contributing to an improvement in the quality of separation of productive formations. However, despite the high strength characteristics of cement stone, full preservation of casing integrity during the perforation is impossible.

It is known [8,9] that the perforation of the productive formation is carried out when the cement stone has gained a certain strength, when destruction is happens under the influence of dynamic loads on the formed stone. In our case, the problem of brittle fracture of the cement stone during perforation is solved by selection of time of shooting operations. According to the principle of the proposed procedure well completion should be carried out during the period when a cement slurry gather plastic strength, i.e. at the stage of transition of a cement slurry into cement stone.

However, the time required for conventional Portland cement slurry to obtain plastic strength is too small and it is often not enough to lower a perforator and perform well completion. One way to increase the time of the set of plastic strength is the input of various surfactants (surfactants) into the cement composition [10].

So, it is important to study the effect of polymers on the processes of structure formation of a polymer-cement slurry as well as other rheological and physical and mechanical properties of a slurry suspension and stone.

\section{Materials and reagents}

Studies and analysis of various polymers, plasticizer agents input to the slurry suspension as inhibitors for strengthening of cement mixture were carried out in order to obtain a cement slurry with required plastic properties $[11,12]$. There was a variety of surfactants tested both non-ionogenic and ionogenic, including cationic and anionic. For different reasons (such as high cost, instability of properties, toxicity etc.) domestic polymers were chosen as plasticizer reagents that are as follows: low molecular weight cationic alkylbenzylmethylammonium chloride (molecular weight 360) and nonionic high molecular weight polyvinylpyrrolidone (PVP) (molecular weight 4600 000). That reagents are translucent colorless liquids with full solubility in water, resistant to salts of polyvalent metals, mineralized water and high temperatures (up to $100^{\circ} \mathrm{C}$ ).

\section{Experimental studies of physical and mechanical properties of a cement slurry and cement stone}

The studies carried out to learn the plastic strength of a polymer-cement solution containing alkylbenzylmethylammonium chloride showed that at a concentration of $0.1-0.3 \%$ of the weight of the cement, time for plastic strengthening increases by 1.5 times compared to the conventional PTC-100, while preserving the rheological properties (Fig. 1).

As can be seen from the Fig. 1, plastic strength set time is divided into three stages such as stage I for the time reqired for coagulation structure of the cement slurry to set. Due to unbound water in a system that structure ensures iflow of the slurry to the perforation holes. The stage II corresponds to a period when coagulation structure of the cement suspension transits into the crystallization one. At this period the cement slurry gains plastic strength but has not yet formed a crystalline 
structure. At this time cumulative and bullet perforation is most beneficial due to the plasticity of a cement slurry, since there is no brittle fracture of a cement system. The stage III corresponds to the time when cement stone gains a crystallization structure. A perforation carried in this period leads to the brittle fracture of the casing in the annulus.

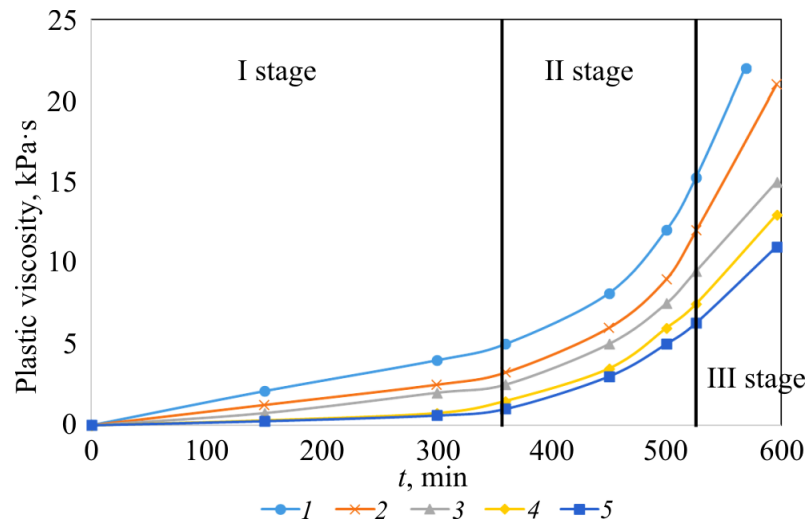

Fig. 1. Dependence of plastic strength of a cement slurry with a plasticizer reagent on hardening time: 1 - PTC-100; 2 - PTC-100 with reagent catamine, $0.1 \% ; 3$ - PTC-100 with reagent catamine, $0.2 \%$; 4 - PTC-100 with reagent catamine, $0.3 \% ; 5$ - PTC- 100 with reagent catamine, $0.2 \%+$ PVP reagent, $0.2 \%$

It can be seen from the graph, that the basic cement slurry with a water/cement ratio of 0.5 is gains plastic strength much faster compared to the polymer-cement suspension. This time is often not enough to conduct cementing works. Besides, by the time of completion the slurry is finally converted into a low permeable hard cement stone, which leads to brittle fracture of the casing during perforation jobs. Increase in time when formation of cement stone starts allows reducing the destructive effect of cumulative and bullet perforators. A mixture of alkylbenzylmethylammonium chloride and PVP at a percentage concentration of $0.2 \%$ by weight of the binder increases the plastic strength of a cement slurry in 1.8 times.

However, determination of the plastic strength set time does not give a complete picture of kinetics of the structure formation of a cement stone. In this regard, consistency parameters of a polymer cement slurry were studied (Fig. 2).

Cement slurry solidification curves reflect that in early stages of structure formation the body of the base cement slurry with a water/cement ratio of 0.5 is higher than a solution with catamine input. However, after that a base solution body continues to decrease, a slurry with reagent input remains fairly stable (about 60 rel. units of body). The same is observed when a high-molecular PVP is input to the polymer-cement mixture. A mixture body remains sufficiently stable up to 9 hours longer than in a conventional cement slurry.

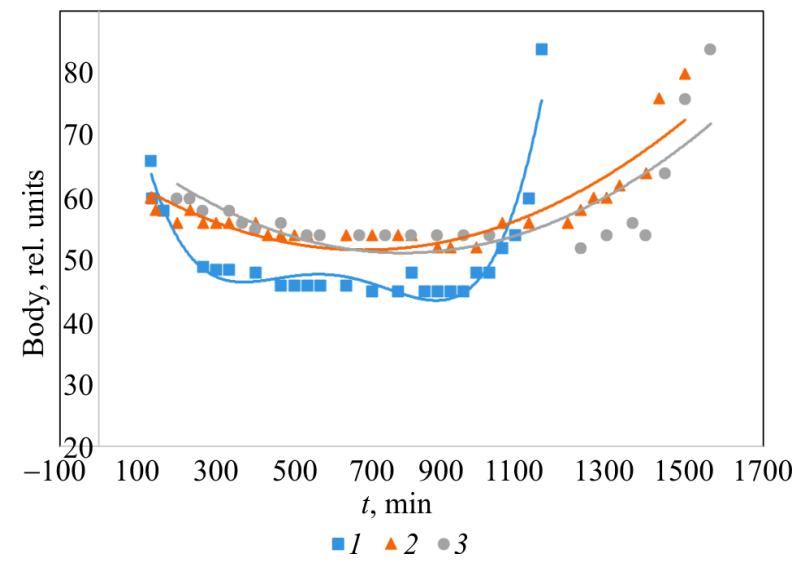

Fig. 2. Graph of dependence of change in the consistency of cement slurries on time: 1 - portland cement-100;2 - portland cement-100 with $0.2 \%$ of catamine; 3 - portland cement- 100 with a polymer mixture of $0.2 \%$ catamine and $0.2 \%$ PVP

Increase in system stability is caused by slow formation of a crystalline structure of the formed slurry suspension. As a result, plasticity strength of the polymer solution increases in comparison with conventional sement slurry.

When cementing a well it is also necessary to take into account such a property as the mobility of a cement slurry that characterizes the possibility of pumping, determines the amount of hydraulic resistances when cementing and features of behavior of a slurry when filling the channels. In practice, the mobility is estimated from spreadability of a cement slurry [13].

Conducted experimental studies showed that input of a reagent-plasticizer of catamine (alkylbenzylmethylammonium chloride) to the slurry suspension substantially increases the spreading of the solution (Table 1).

As can be seen from the table, input of high molecular PVP polymer into the polymer-cement mixture slightly reduces system mobility, but remains within the normal range.

The studies conducted showed that the polymer catamine increases the time required for a slurry to solidificate, and solidification time increases by $20 \%$ when a high-molecular PVP is input to the mixture (Table 2). 
Table 1

Results of the cement spreadability test

\begin{tabular}{|l|c|}
\hline \multicolumn{1}{|c|}{ Type of solution } & Spreadability, cm \\
\hline Portland cement- 100 & 22 \\
\hline Portland cement- $100+$ catamine, $0.1 \%$ & $>25$ \\
\hline Portland cement- $100+$ catamine, $0.2 \%$ & $>25$ \\
\hline Portland cement- $100+$ catamine, $0.3 \%$ & $>25$ \\
\hline $\begin{array}{l}\text { Portland cement- } 100+\text { catamine, } \\
0.1 \%+\text { PVP, } 0.2 \%\end{array}$ & 22 \\
\hline $\begin{array}{l}\text { Portland cement- } 100+\text { catamine, } \\
0.2 \%+\text { PVP, } 0.2 \%\end{array}$ & 23 \\
\hline $\begin{array}{l}\text { Portland cement- } 100+\text { catamine, } \\
0.3 \%+\text { PVP, } 0.2 \%\end{array}$ & 23 \\
\hline $\begin{array}{l}\text { Portland cement- } 100+\text { catamine, } \\
0.1 \%+\text { T66, } 0.1 \%\end{array}$ & 21 \\
\hline $\begin{array}{l}\text { Portland cement- } 100+\text { catamine, } \\
0.2 \%+\text { T66, } 0.1 \%\end{array}$ & 21 \\
\hline $\begin{array}{l}\text { Portland cement- } 100+\text { catamine, } \\
0.3 \%+\text { T66, } 0.1 \%\end{array}$ & 22 \\
\hline Portland cement- $100+$ catamine, $0.1 \%+$ oil & 22 \\
\hline Portland cement- $100+$ catamine, $0.2 \%+$ oil & 22 \\
\hline Portland cement- $100+$ catamine, $0.3 \%+$ oil & 22 \\
\hline
\end{tabular}

Table 2

Solidification time (beginning and end) of cement slurries

\begin{tabular}{|l|c|c|}
\hline \multicolumn{1}{|c|}{$\begin{array}{c}\text { Composition } \\
\text { of cement material }\end{array}$} & $\begin{array}{c}\text { Beginning of } \\
\text { solidification, } \mathrm{h}\end{array}$ & $\begin{array}{c}\text { End of } \\
\text { solidification, } \mathrm{h}\end{array}$ \\
\hline $\begin{array}{l}\text { Portland cement-100 } \\
\text { Portland cement-100+ } \\
+ \text { catamine, } 0.1 \%\end{array}$ & 10 & 20.3 \\
\hline $\begin{array}{l}\text { Portland cement-100+ } \\
+ \text { catamine, } 0.2 \%\end{array}$ & 12.8 & 21.3 \\
\hline $\begin{array}{l}\text { Portland cement-100+ } \\
+ \text { catamine, } 0.3 \%\end{array}$ & 13.2 & 23 \\
\hline $\begin{array}{l}\text { Portland cement-100+ } \\
+ \text { catamine, } 0.2 \%+ \\
+ \text { PVP, } 0.2 \%\end{array}$ & 13.3 & 26.3 \\
\hline $\begin{array}{l}\text { Portland cement-100+ } \\
+ \text { catamine, } 0.1 \%+ \\
+ \text { T66, } 0.1 \%\end{array}$ & 12 & 20.5 \\
\hline $\begin{array}{l}\text { Portland cement- } 100+ \\
+ \text { catamine, } 0.2 \%+ \\
+ \text { T66, } 0.1 \%\end{array}$ & 12.5 & 22.5 \\
\hline $\begin{array}{l}\text { Portland cement-100+ } \\
+ \text { catamine, } 0.3 \%+ \\
+ \text { T66, } 0.1 \%\end{array}$ & 13 & 22 \\
\hline $\begin{array}{l}\text { Portland cement-100+ } \\
+ \text { catamine, } 0.2 \%+\text { oil }\end{array}$ & & 21.5 \\
\hline
\end{tabular}

Increase in solidification time of the polymercement suspension, that includes alkylbenzylmethylammonium chloride and PVP, is explained by hydrophobization of cement clinker which leads to cement hydration slow down.

It is known [14-18] that the majority of surfactants (both ionic and non-ionic) have a significant disadvantage such as foaming of water- based cement slurries. That negatively affects the strength of a cement stone due to a formation of large porosity in a system. There is a deterioration of the quality of inter-layer insulation in wells as a consequence. In this connection, it is relevant to study the reduction in the foaming of a cement slurry by input of various defoamers into the composition of a cement slurry. According to the analysis of reagents of both domestic (coal, T-66 etc.) and foreign (phenylamine, siloxane etc.) production it is showed that the economic and quality indicators among the variety of reagents the most advantageous is the reagent T-66 (pine oil). The foaming significantly decreases, and completely disappears in the oil environment when the content of T-66 in the polymer-cement mixture is $0.1 \%$ to the weight of dry cement.

Experimental studies have shown that the input of a reagent T-66 into the polymer-cement slurry suspension does not significantly affect the rheological properties (see Table 1).

As can be seen from the Table 1, the input of the defoamer T-66 or oil into the polymercement mixture slightly reduces the spreadability of the polymer cement test. The decrease in spreadability of the polymer-cement slurry, in which the defoamer is presented, is explained by decrease in surface tension of the polymer reacting with cement clinker. That reduces the size of hydrate cover of polymer substance around the crystal, and most of the cement hydrates with water, which decreases the mobility of a suspension.

Defoamer T-66 reduces the solidification time of polymer-cement slurry by $15 \%$. Input of the oil emulsion into the slurry suspension does not affect the solidification of solution (see Table 2).

Analysis of the data of Table 1 and 2 shows that the proposed T-66 reagent reduces the foaming of the polymer-cement suspension and does not change its rheological properties.

The properties of the polymer-cement slurry depend on conditions for solidification of a cement slurry, which are determined by the environment temperature [19]. In our case, conditions were simulated. There were productive strata with mean temperature regimes $\left(20,40,60,80,100^{\circ} \mathrm{C}\right)$ under conditions.

Cement slurries that are tempered on water and commonly used for cementing of productive formations of oil wells, an amount of water input 
during tempering is enough for complete hydration reaction. However, in the porous medium of the productive formation water can flow deep into the formation. That stops hydration reaction and change the structure of a cement stone [20-22]. In this regard, the effect of low and high molecular polymers on flow properties of a cement slurry with a water/cement ratio of 0.5 was studied (Fig. 3).

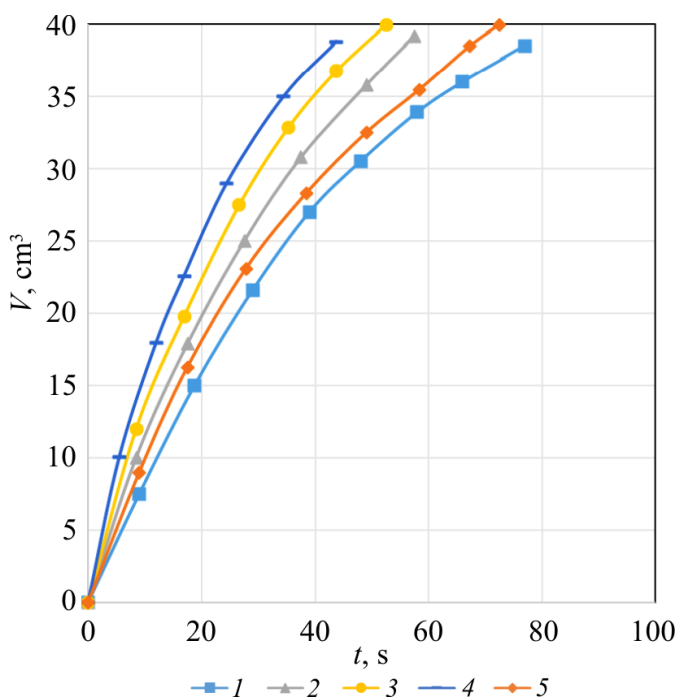

Fig. 3. Dependence of fluid loss of cement slurries on the concentration of plasticizer reagents: 1 - Portland cement-100; 2 - Portland cement-100 + catamine, $0.1 \%$; 3 - Portland cement- $100+$ catamine, $0.2 \% ; 4$ - Portland cement-100 + catamine, $0.3 \% ; 5-$ Portland cement-100 + catamine, $0.2 \%$ and PVP, $0.2 \%$

It is known that a high flow index in cement slurries is undesirable, so the task was to reduce the value of fluid loss, as well as to increase the sedimentation time of the polymer-cement suspension. Input of catamine reagent in the cement slurry increased the water loss, however, PVP stabilizes the system and flow rates are reduced to $30 \%$ compared to the cement slurry where catamine is presented in amount of $0.3 \%$. Cement slurries remain sufficiently stable in the sedimentation ratio (Table 3 ).

Table 3

Water loss of cement suspensions

\begin{tabular}{|l|c|}
\hline \multicolumn{1}{|c|}{ Composition of cement material } & Water loss per $3 \mathrm{~h}, \%$ \\
\hline Portland cement- 100 & 2.1 \\
\hline Portland cement- $100+$ catamine, $0.1 \%$ & 2.3 \\
\hline Portland cement $-100+$ catamine, $0.2 \%$ & 2.5 \\
\hline Portland cement- $100+$ catamine, $0.3 \%$ & 2.6 \\
\hline $\begin{array}{l}\text { Portland cement- } 100+\text { catamine, } \\
0.2 \%+\text { PVP, } 0.2 \%\end{array}$ & 2.1 \\
\hline
\end{tabular}

Cement slurry hydration is usually accompanied by repackaging of the water molecules adsorbed on cement particles, which results in a change in volume of solidificating cement stone. The specific surface of hydration products is 3-4 orders of magnitude higher than the specific surface area of the initial binder. Chemically bounded water takes up less volume than the free one. As a result, there is a volume change, called contraction, is observed, which is approximately equal to the volume of water that has entered into a chemical reaction when the binder interacts with water and crystalline hydrates (neoplasms) are formed [23-25].

According to V.V. Nekrasov [26], it is possible to apply with good accuracy the estimated contraction value equal to $7-9 \mathrm{ml}$ per $100 \mathrm{~g}$ of cement for the majority of Portland cements. The Fig. 4 shows the values of contraction developed by cement slurries with different percentages of polymers in a system. For example, PTC-100 has a water/cement ratio of 0.5 . Contraction reaches $47 \%$ of the limit value by 28 days and slows down significantly after. Due to the fact that initial polymers input to the cement mix increase the hydration time of the Portland cement clinker, contraction reaches $50-56 \%$ (depending on the percentage of polymer in the plugging mixture) by 28 days of polymer cement stone solidifiacation.

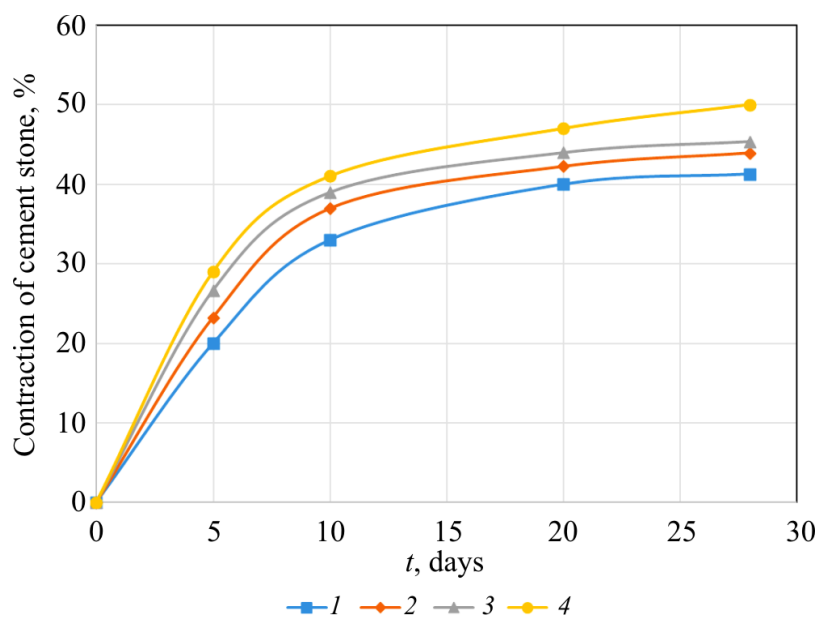

Fig. 4. Dependence of the value of cement stone contraction on percentage content of the reagentplasticizer of catamine: 1 - Portland cement-100; 2 - Portland cement-100 + catamine, $0.1 \%$; 3 - Portland cement- $100+$ catamine, $0.2 \% ; 4$ - Portland cement- $100+$ catamine, $0.2 \%$ and PVP, $0.2 \%$

Results of experimental work show that the longer the process of hydrating cement clinker the higher is the contraction effect for a cement slurry. 
Operation of oil and gas wells requires stable work of casing which is resistant to increased external and internal pressures. That is ensured by the formation of a continuous cement ring with certain physical and mechanical characteristics, one of which is the strength of cement stone [27, 28].

Mechanical strength of the casing depends on a number of factors such as type of a cement, watercement ratio, presence of chemical additives, conditions of solidification [29].

There were experiments conducted in order to determine strength values of the formed cement stone for compression and bending (Fig. 5).

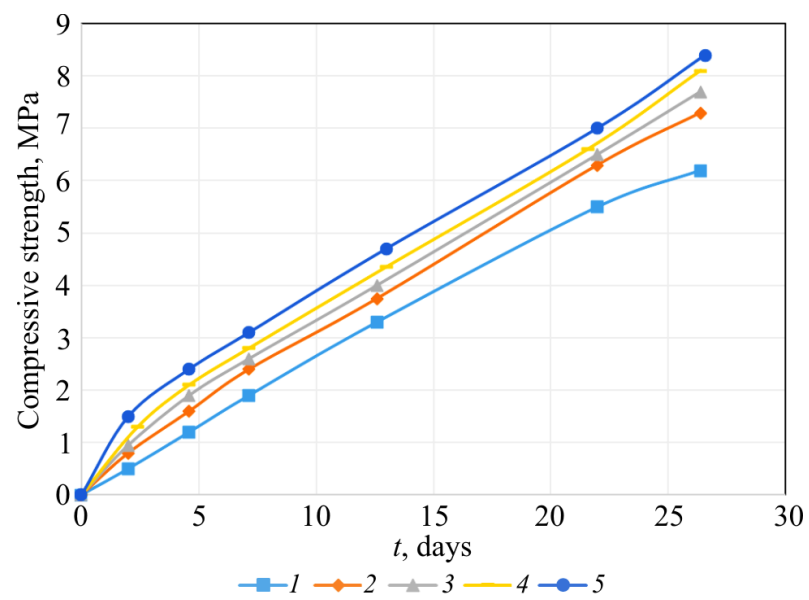

Fig. 5. Dependence of strength of a cement stone for compression on the content of polymers in its composition: 1 - Portland cement-100; 2 - Portland cement-100 + catamine, $0.1 \% ; 3$ - Portland cement$100+$ catamine, $0.2 \% ; 4$ - Portland cement-100+ + catamine, $0.3 \% ; 5$ - Portland cement-100 + catamine,

$$
0.2 \%+\text { PVP, } 0.2 \%
$$

As can be seen in the Fig. 5, the strength of the stone for uniaxial compression, which contains catamine reagent-plasticizer, is higher by 110 $180 \%$ depending on the percentage of the reagent and continues to grow. However, input of the reagent-defoamer (T-66 in our case) into the polymer-cement slurry sharply increases the strength in initial period of formation of the cement stone (Fig. 6), solidification rate decreases after 10 days and changes significantly. However, in general, input of a defoamer reduces the strength of a polymer cement stone by $5-10 \%$.

Such the phenomenon is explained by the fact that the growth rate of the cement clinker crystals is maximal on the first day of solidification of the slurry suspension. Then, the dynamics of formation of strong bonds decreases, while the polymer-cement stone without input antifoam is just beginning to gain maximum strength. A polymer cement slurry, which contains the reagent composition (catamine and PVP) is less prone to accelerated solidification. That is explained by the higher stability of the system to the defoamer T-66.

The strength of a cement stone for bending was studied untill the 28th day of solidification, since during this period the strength of the polymercement material still occurred (Fig. 7).

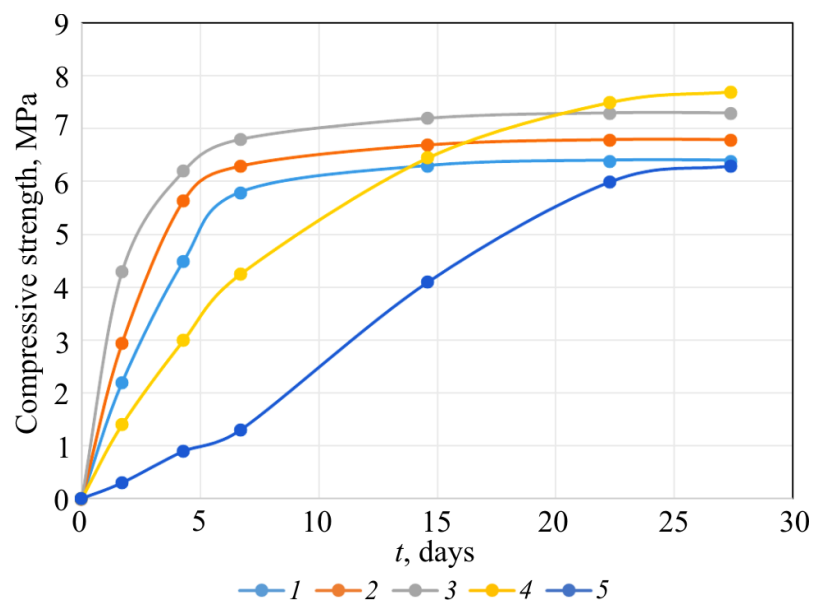

Fig. 6 Dependence of strength of a polymer cement stone with input of a defoamer T-66: 1 - Portland cement-100 + catamine, $0.1 \%+$ T-66, $0.1 \%$; 2 - Portland cement-100 + catamine, $0.2 \%+\mathrm{T}-66$, $0.1 \% ; 3$ - Portland cement- $100+$ catamine, $0.3 \%+$ T- 66 , $0.1 \% ; 4$ - Portland cement-100 + catamine, $0.2 \%+$ PVP, $0.2 \%+\mathrm{T}-66,0.1 \% ; 5-$ Portland cement-100, water/cement $=0.5$

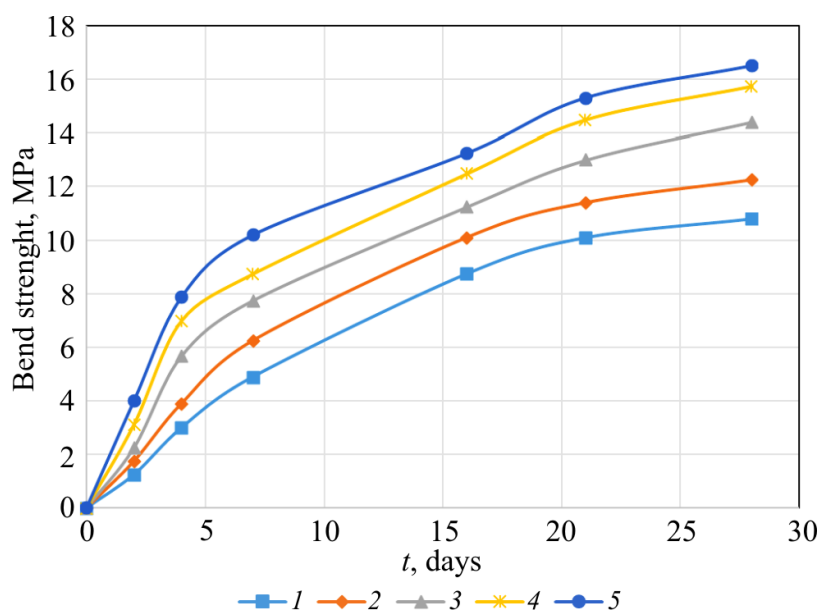

Fig. 7. Dependence of change in the strength of a polymer cement stone on bending: 1 - Portland cement$100 ; 2$ - Portland cement-100 + catamine, $0.1 \%$; 3 - Portland cement-100 + catamine, $0.2 \%$; 4 - Portland cement-100 + catamine, $0.3 \% ; 5-$ Portland cement-100 + catamine, $0.2 \%+$ PVP, $0.2 \%$ 
It can be seen on the Fig. 7 that bend strength increases by $128 \%$ compared to the base portland cement-100 (water/cement $=0.5)$ with input of $0.3 \%$ of catamine. There is an increase in strength by $165 \%$ at concentration of catamine of $0.2 \%$ and $0.2 \%$ of PVP reagent.

A completely different picture of the solidification of a polymer-cement stone is observed when a T-66 antifoaming agent is injected into a cement slurry. There is an intensive growth of cement stone strength during the first five days of its solidification, after which the crystal growth rate decreases and changes insignificantly (Fig. 8).

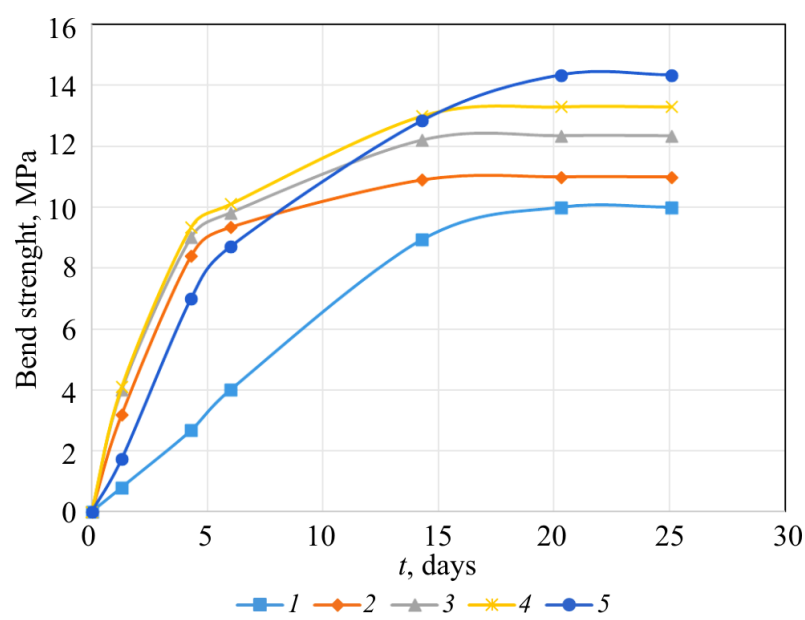

Fig. 8. Dependence of the bend strength change of the polymer cement material with T-66: 1 - Portland cement-100;2 - Portland cement-100 + catamine, $0.1 \%+\mathrm{T}-66,0.1 \% ; 3-$ Portland cement-100 + + catamine, $0.2 \%+\mathrm{T}-66,0.1 \% ; 4$ - Portland cement$100+$ catamine, $0.3 \%+\mathrm{T}-66,0.1 \% ; 5$ - Portland cement-100 + catamine, $0.2 \%+$ PVP, $0.2 \%+$ T-66, $0.1 \%$

That phenomenon is explained by the fact that the defoamer increases the surface tension of water (which explains the decrease in foam in the slurry), and cement clinker particles react more rapidly with a dispersion medium, as a result of which intensive formation of the coagulation structure and then rapid growth of the crystals in the system are observed.

Input of PVP reagent into the polymer-cement slurry allows to reduce the influence of the defoamer (see Fig. 8) and reduce the intensity of solidification. At the same time at the end of 28 days the value of bend strength is $50 \%$ higher than for ordinary cement suspension (in comparison with the base cement slurry).
It is known that the qualitative isolation of productive formations and cementing of the well walls depend both on strength of the cement stone and on adhesion of the solidificating cement slurry and stone with rocks and metal of the casing pipes [30].

Experiments conducted to study the adhesion strength of cement stone with the metal (adhesion) showed that the polymer catamine input to the cement slurry increases the adhesion strength by $133 \%$ (Table 4) compared to the base Portland cement stone, and the antifoaming agent T-66 significantly reduces the adhesion properties of casing.

Table 4

Strength of adhesion of cement stone to metal

\begin{tabular}{|l|c|c|c|}
\hline \multirow{2}{*}{ Composition } & \multicolumn{3}{|c|}{$\begin{array}{c}\text { Adhesion of cement } \\
\text { stone with metal, MPa }\end{array}$} \\
\cline { 2 - 4 } & 3 days & 6 days & 8 days \\
\hline Portland cement-100 & 2.5 & 3.2 & 3.8 \\
\hline Portland cement-100 + catamine, 0.1 \% & 3.5 & 5.2 & 6 \\
\hline Portland cement-100 + catamine, 0.2 \% & 4 & 6.1 & 7.2 \\
\hline Portland cement-100 + catamine, 0.3 \% & 4.3 & 8 & 8.5 \\
\hline $\begin{array}{l}\text { Portland cement-100 + catamine, } \\
0.2 \%+\text { PVP, 0.2 \% }\end{array}$ & 5.2 & 8.6 & 10 \\
\hline $\begin{array}{l}\text { Portland cement-100 + catamine, } \\
0.1 \%+\text { T-66 }\end{array}$ & 2 & 1.6 & 1.4 \\
\hline $\begin{array}{l}\text { Portland cement-100 + catamine, } \\
0.2 \%+\text { T-66 }\end{array}$ & 2.5 & 2 & 1.8 \\
\hline $\begin{array}{l}\text { Portland cement-100 + catamine, } \\
0.3 \%+\text { T-66 }\end{array}$ & 2.8 & 2.1 & 2 \\
\hline $\begin{array}{l}\text { Portland cement-100 + catamine, } \\
0.2 \%+\text { PVP, 0.2 \% + T-66 }\end{array}$ & 6 & 5.3 & 5.2 \\
\hline
\end{tabular}

The highes adhesion of the polymer cement stone is achieved by 8 days of solidification, after which the adhesion strength changes insignificantly and by the 28th day the difference does not exceed $7-9 \%$. So, the adhesion of samples, in which the reagent-plasticizer of catamine and mixture of PVP and catamine increases in comparison with the base cement.

The highest adhesion is observed in the cement stone, which contains a mixture of reagents (catamine, $0.2 \%$, and PVP, $0.2 \%$ ), and is $192 \%$ relative to a usual Portland cement-100.

\section{Conclusions}

Based on the experimental studies conducted, the following main conclusions can be drawn:

1. Results obtained allow to state the effectiveness of carrying out perforating jobs during the stage II of getting of plastic strength of a cement slurry. 
2. That is possible to achieve the required time for plastic strength to grow of a cemet slurry for the successful perforation by the input of catamine and PVP to a low molecular polymer of into the cement mixture, when their concentration in the solution is $0.2 \%$ of the weight of the binder.

3. Input of the catamine reagent-plasticizer and composition of catamine and PVP increases the spreadability of the cement slurry significantly (more than $25 \mathrm{~cm}$ ).

4. Plasticizer reactants contribute to a significant increase in strength of cement stone for compression (by $200 \%$ after 28 days of solidification) and bending (by $250 \%$ ) and increase adhesion properties of cement stone to metal (by $80 \%$ ).

\section{References}

1. Mardanov M.S. Povyshenie debitov i dolgovechnosti krepi skvazhin razrabotkoi i vnedreniem shchadiashchikh rezhimov vtorichnogo vskrytiia produktivnykh plastov [Increase in flow rates and durability of well casing by development and implementation of sparing regimes of secondary penetration of reservoirs]. Problemy razrabotki mestorozhdenii uglevodorodnykh $i$ rudnykh poleznykh iskopaemykh, 2014, no.1, pp.480-483.

2. Sudong H., Xiao Y. Properties and application of oil-well cement enhanced with a novel composite toughening agent. Petroleum Science, 2007, vol.4, no.2, pp.52-59. DOI: $10.1007 / \mathrm{BF} 03187442$

3. Ivanova I.S., Pustovgar A.P., Ganiev S.R. Osobennosti sukhikh smesei dlia tsementirovaniia neftegazovykh skvazhin [Features of dry mixtures for cementing oil and gas wells]. Neftegazovoe delo. Elektronnyi nauchnyi zhurnal, 2014, no.4, pp.18-35. DOI: 10.17122/ogbus-2014-4-18-35

4. Melekhin A.A., Krysin N.I., Tret'iakov E.O. Analiz faktorov, vliiaiushchikh na dolgovechnost' tsementnogo kamnia za obsadnoi kolonnoi [Analysis of factors affecting the life time period of cement stone behind a casing string]. Neftepromyslovoe delo, 2013, no.9, pp.77-82.

5. Gaivoronskii I.N., Kostitsyn V.I., Savich A.D., Chernykh I.A., Shumilov A.V. Povyshenie effektivnosti vtorichnogo vskrytiia produktivnykh plastov [Ways of improvement of reservoir completion efficiency]. Neftianoe khoziaistvo, 2016, no.10, pp.62-65.

6. Behrmann L., Brooks J.E., Farrant S., Fayard A., Venkitaraman A., Brown A., Michel Ch., Noordermeer A., Smith $\mathrm{Ph}$., Underdown D. Perforating practices that optimize productivity. Oilfield Review, 2000, vol.12, no.1, pp.52-74.

7. Ishbaev G.G., Dil'miev M.R., Ishbaev R.R., Latypov T.R. Razrabotka tamponazhnykh materialov povyshennoi udarnoi prochnosti [Development of grouting materials with high impact strength]. Burenie $i$ neft', 2015, no.9, pp.38-41.

8. Petrov N.A., Sultanov V.G., Davydova I.N., Konesev G.V. Povyshenie kachestva pervichnogo i vtorichnogo vskrytiia neftianykh plastov [Improving the quality of primary and secondary oil stripping]. Ed. G.V. Konesev. Saint Petersburg, Nedra, 2007, 548 p.

9. Fridliander L.Ia. et al. Prostrelochno-vzryvnaia apparatura [Shooting and blasting equipment]. Moscow, Nedra, 1990, 199 p.
10. Silin M.A., Magadova L.A., Efimov M.N., Efimov N.N., Shidginov Z.N. Tamponazhnye rastvory na uglevodorodnoi osnove dlia remontno-izoliatsionnykh rabot [Oil-based grouting mortars for repair and insulation work]. Trudy rossiiskogo gosudarstvennogo universiteta nefti i gaza imeni I.M. Gubkina, 2010, no.3, pp.87-94.

11. Petrov N.A., Davydova I.N. Issledovanie nekotorykh polimernykh reagentov otechestvennogo proizvodstva [A study of some polymeric reagents domestic production]. Elektronnyi nauchnyi zhurnal neftegazovoe delo, 2016, no.4, pp.6-39. DOI: 10.17122/ogbus-2016-4-6-39

12. Broni-Bediako E., Joel O.F., Ofori-Sarpong G. Oil well cement additives: a review of the common types. Oil and Gas Research, 2016, vol.2, no.1, pp.1-7. DOI: 10.4172/ogr.1000112.

13. Akhrimenko V.E., Pashchevskaia N.V. Ispol'zovanie melassy v kachestve plastifikatora tamponazhnykh rastvorov [Usage of molasses as plasticizer of grouting mortars]. Stroitel'stvo neftianykh $i$ gazovykh skvazhin na sushe i na more, 2014, no.1, pp.35-37.

14. Bulatov A.I. Upravlenie fiziko-mekhanicheskimi svoistvami tamponazhnykh sistem [Management of physical and mechanical properties of oil-well systems]. Moscow, Nedra, 1976, 298 p.

15. Volzhenskii A.V., Burov Iu.S., Kolokol'nikov V.S. Mineral'nye viazhushchie veshchestva [Mineral binders]. Moscow, Stroiizdat, 1979, $476 \mathrm{p}$.

16. Nikolaev N.I., Nifontov Iu.A., Dernov D.A., Toib R.R. Pokolenie otechestvennykh polimerov dlia bureniia skvazhin [The generation of domestic polymers for drilling wells]. Promyshlennost' segodnia, 2004, no.1, pp.19-23.

17. Derkach S.R., Berestova G.I., Motyleva T.A. Ispol'zovanie PAV dlia intensifikatsii neftedobychi pri pervichnom i vtorichnom vskrytii plastov [The use of surfactants for the intensification of oil production during primary and secondary opening of seams]. Vestnik murmanskogo gosudarstvennogo tekhnicheskogo universiteta, 2010, no.4-1, pp.784-792.

18. Sherstnev N.M., Gugvich L.M., Bulina I.G. Primenenie kompozitsii PAV pri ekspluatatsii skvazhin [The use of surfactant compositions in the operation of wells]. Moscow, Nedra, 1988, 184 p.

19. Samsonenko A.V., Simoniants S.L., Samsonenko N.V. Novye tamponazhnye materialy dlia ispol'zovaniia $\mathrm{v}$ usloviiakh normal'nykh i umerennykh temperatur $[\mathrm{New}$ 
cementing materials for use in normal and moderate temperatures]. Stroitel'stvo neftianykh i gazovykh skvazhin na sushe i na more, 2009, no.10, pp.42-47.

20. Tabatabaee Moradi S.Sh., Nikolaev N.I. Free fluid control of oil well cements using factorial design. Journal of engineering research, 2017, vol.5, no.1, pp.220-229.

21. Tabatabaee Moradi S.Sh., Nikolaev N.I. Sedimentation stability of oil well cements in directional wells. IJE Transactions A: Basics, 2017, vol.30, no.7, pp.1105-1109. DOI: 10.5829/ije.2017.30.07a.21

22. Choolaei M., Rashidi A.M., Ardjmand M., Yadegari A., Soltanian H. The effect of nanosilica on the physical properties of oil well cement. Materials Science and Engineering: A, 2012, vol.538, pp.288-294. DOI: 10.1016/j.msea.2012.01.045

23. Bulatov A.I. Formirovanie i rabota tsementnogo kamnia v skvazhine [Formation and work of cement stone in the well]. Moscow, Nedra, 1990, 416 p.

24. Riabova L.I., Shliakhovoi D.S., Timofeeva E.V. Ob"emnye izmeneniia tsementnogo rastvora i kamnia, vliiaiushchie na kachestvo tsementirovaniia skvazhin [Volume changes in cement mortar and stone, affecting the quality of cementing wells]. Neftianoe khoziaistvo, 2008, no.2, pp.40-42.

25. Rubiandini R., Siregar S., Suhascaryo N., Efrial D. The effect of $\mathrm{CaO}$ and $\mathrm{MgO}$ as expanding additives to improve cement isolation strength under HPHT exposure. Journal of Engineering and Technological Sciences, 2005, vol.37, no.1, pp.29-48. DOI: $10.5614 \% 2 F i t b j . e n g . s c i .2005 .37 .1 .3$

26. Berkovich T.M. O kinetike protsessa gidratatsii tsementa [On the kinetics of cement hydration process]. DAN SSSR, 1963, no.5, pp.1127-1130.

27. Ridha S., Irawan S., Ariwahjoedi B. Strength prediction of Class $\mathrm{G}$ oil well cement during early ages by electrical conductivity. Journal of Petroleum Exploration and Production Technology, 2013, vol.3, no.4, pp.303-311. DOI: 10.1007/s13202-013-0075-9

28. Tabatabaee Moradi S.Sh., Nikolaev N.I. Considerations of well cementing materials in high-pressure, high-temperature conditions. IJE Transactions C: Aspects, 2016, no.9, pp.1214-1218. DOI: $10.5829 /$ idosi.ije.2016.29.09c.05

29. Labibzadeh M., Zahabizadeh B., Khajehdezfuly A. Early-age compressive strength assessment of oil well class $\mathrm{G}$ cement due to borehole pressure and temperature changes. Journal of American Science, 2010, vol.6, no.7, pp.38-47. DOI:10.7537/marsjas060710.05

30. Castel A., Foster S.J. Bond strength between blended slag and Class F fly ash geopolymer concrete with steel reinforcement. Cement and Concrete Research, 2015, vol.72, pp.48-53. DOI: 10.1016/j.cemconres.2015.02.016

\section{Библиографический список}

1. Марданов М.С. Повышение дебитов и долговечности крепи скважин разработкой и внедрением щадящих режимов вторичного вскрытия продуктивных пластов // Проблемы разработки месторождений углеводородных и рудных полезных ископаемых. - 2014. - № 1. - С. 480-483.

2. Sudong H., Xiao Y. Properties and application of oil-well cement enhanced with a novel composite toughening agent // Petroleum Science. - 2007. - Vol. 4, № 2. - P. 52-59. DOI: 10.1007/BF03187442

3. Иванова И.С., Пустовгар А.П., Ганиев С.Р. Особенности сухих смесей для цементирования нефтегазовых скважин // Нефтегазовое дело. - 2014. № 4. - C. 18-35. DOI: 10.17122/ogbus-2014-4-18-35

4. Мелехин А.А., Крысин Н.И., Третьяков Е.О. Анализ факторов, влияющих на долговечность цементного камня за обсадной колонной // Нефтепромысловое дело. - 2013. - № 9. C. $77-82$.

5. Повышение эффективности вторичного вскрытия продуктивных пластов / И.Н. Гайворонский, В.И. Костицын, А.Д. Савич, И.А. Черных, А.В. Шумилов // Нефтяное хозяйство. - 2016. - № 10. - С. 62-65.

6. Perforating practices that optimize productivity / L. Behrmann, J.E. Brooks, S. Farrant, A. Fayard, A. Venkitaraman, A. Brown, Ch. Michel, A. Noordermeer, $\mathrm{Ph}$. Smith, D. Underdown // Oilfield Review. - 2000. Vol. 12, № 1. - P. 52-74.

7. Разработка тампонажных материалов повышенной ударной прочности / Г.Г. Ишбаев, М.Р. Дильмиев,
Р.Р. Ишбаев, Т.Р. Латыпов // Бурение и нефть. - 2015. № 9. - C. $38-41$.

8. Повышение качества первичного и вторичного вскрытия нефтяных пластов / Н.А. Петров, В.Г. Султанов, И.Н. Давыдова, Г.В. Конесев; под ред. Г.В. Конесева. СПб.: Недра, 2007. - 548 с.

9. Прострелочно-взрывная аппаратура / Л.Я. Фридляндер [и др.]. - М.: Недра, 1990. - 199 с.

10. Тампонажные растворы на углеводородной основе для ремонтно-изоляционных работ / М.А. Силин, Л.А. Магадова, М.Н. Ефимов, Н.Н. Ефимов, 3.Н. Шидгинов // Труды российского государственного университета нефти и газа им. И.М. Губкина. - 2010. № 3. - С. 87-94.

11. Петров Н.А., Давыдова И.Н. Исследование некоторых полимерных реагентов отечественного производства // Нефтегазовое дело. - 2016. - № 4. C. 6-39. DOI: 10.17122/ogbus-2016-4-6-39

12. Broni-Bediako E., Joel O.F., Ofori-Sarpong G. Oil well cement additives: a review of the common types // Oil and Gas Research. - 2016. - Vol. 2, № 1. - P. 1-7. DOI: 10.4172 /ogr.1000112.

13. Ахрименко В.Е., Пащевская Н.В. Использование мелассы в качестве пластификатора тампонажных растворов // Строительство нефтяных и газовых скважин на суше и на море. - 2014. № 1. - С. 35-37.

14. Булатов А.И. Управление физико-механическими свойствами тампонажных систем. - М.: Недра, 1976. 298 c. 
15. Волженский А.В., Буров Ю.С., Колокольников В.С. Минеральные вяжущие вещества. - М.: Стройиздат, 1979. $-476 \mathrm{c}$.

16. Поколение отечественных полимеров для бурения скважин / Н.И. Николаев, Ю.А. Нифонтов, Д.А. Дернов, Р.Р. Тойб // Промышленность сегодня. 2004. - № 1. - С. 19-23.

17. Деркач С.Р., Берестова Г.И., Мотылева Т.А. Использование ПАВ для интенсификации нефтедобычи при первичном и вторичном вскрытии пластов // Вестник Мурманского государственного технического университета. - 2010. - № 4-1. - С. 784-792.

18. Шерстнев Н.М., Гугвич Л.М., Булина И.Г. Применение композиций ПАВ при эксплуатации скважин. - М.: Недра,1988. - 184 с.

19. Самсоненко А.В., Симонянц С.Л., Самсоненко Н.В. Новые тампонажные материалы для использования в условиях нормальных и умеренных температур // Строительство нефтяных и газовых скважин на суше и на море. -2009 . - № 10. - С. 42-47.

20. Tabatabaee Moradi S.Sh., Nikolaev N.I. Free fluid control of oil well cements using factorial design // Journal of engineering research. - 2017. - Vol. 5, № 1. - P. 220-229.

21. Tabatabaee Moradi S.Sh., Nikolaev N.I. Sedimentation stability of oil well cements in directional wells // IJE Transactions A: Basics. - 2017. - Vol. 30, № 7. P. 1105-1109. DOI: 10.5829/ije.2017.30.07a.21

22. The effect of nanosilica on the physical properties of oil well cement / M. Choolaei, A.M. Rashidi, M. Ardjmand, A. Yadegari, H. Soltanian // Materials Science and Engineering: A. 2012. - Vol. 538 - P. 288-294. DOI: 10.1016/j.msea.2012.01.045
23. Булатов А.И. Формирование и работа цементного камня в скважине. - М.: Недра,1990. - 416 с.

24. Рябова Л.И., Шляховой Д.С., Тимофеева Е.В. Объемные изменения цементного раствора и камня, влияющие на качество цементирования скважин // Нефтяное хозяйство. - 2008. - № 2. - С. 40-42.

25. The effect of $\mathrm{CaO}$ and $\mathrm{MgO}$ as expanding additives to improve cement isolation strength under HPHT exposure / R. Rubiandini, S. Siregar, N. Suhascaryo, D. Efrial // Journal of Engineering and Technological Sciences. - 2005. - Vol. 37, № 1. - P. 29-48. DOI: 10.5614 \%2Fitbj.eng.sci.2005.37.1.3

26. Беркович Т.М. О кинетике процесса гидратации цемента // ДАН СССР. - 1963. - № 5. - С. 1127-1130.

27. Ridha S., Irawan S., Ariwahjoedi B. Strength prediction of Class $\mathrm{G}$ oil well cement during early ages by electrical conductivity // Journal of Petroleum Exploration and Production Technology. - 2013. - Vol. 3, № 4. P. 303-311. DOI: 10.1007/s13202-013-0075-9

28. Tabatabaee Moradi S.Sh., Nikolaev N.I. Considerations of well cementing materials in high-pressure, high-temperature conditions // IJE Transactions C: Aspects. - 2016. - № 9. P. 1214-1218. DOI: 10.5829/idosi.ije.2016.29.09c.05

29. Labibzadeh M., Zahabizadeh B., Khajehdezfuly A. Early-age compressive strength assessment of oil well class $\mathrm{G}$ cement due to borehole pressure and temperature changes // Journal of American Science. - 2010. - Vol. 6, № 7. - P. 38-47. DOI: 10.7537/marsjas060710.05

30. Castel A., Foster S.J. Bond strength between blended slag and Class F fly ash geopolymer concrete with steel reinforcement // Cement and Concrete Research. - 2015. Vol. 72. - P. 48-53. DOI: 10.1016/j.cemconres.2015.02.016

Please cite this article in English as:

Nikolaev N.I., Usmanov R.A., Tabatabaee Moradi S.Sh., Hernandez Requena J.R. Development of slurries and study of properties of cement mixtures to increase the quality of well completion. Perm Journal of Petroleum and Mining Engineering, 2017, vol.16, no.4, pp.321-330. DOI: 10.15593/2224-9923/2017.4.3

Просьба ссылаться на эту статью в русскоязычных источниках следующим образом:

Разработка составов и исследование свойств тампонажных смесей для повышения качества вторичного вскрытия продуктивных пластов / Н.И. Николаев, Р.А. Усманов, С.Ш. Табатабаи Моради, Дж.Р. Эрнандес Рекена // Вестник Пермского национального исследовательского политехнического университета. Геология. Нефтегазовое и горное дело. - 2017. - T.16, №4. - C.321-330. DOI: $10.15593 / 2224-9923 / 2017.4 .3$ 